\title{
Prostate cancer in women - a rare medical event or a new disease of peer-reviewed science publications?
}

\author{
Justyna Ożegalska-Trybalska
}

Chair of Intellectual Property Law, Jagiellonian University, Krakow, Poland

Reliability of research and publications are the pillars of modern science. Unfortunately, its ethos is more often built not on the quality of research results but on the number of publications and citations, which are the essential criteria for evaluating scientific achievements. The citation rate of published articles also influences the rankings and prestige of scientific journals, indexed based on the Journal Impact Factor (JIF). JIF and the reviewing process should effectively ensure the quality and originality of publications. Unfortunately, sometimes they do not guarantee it.

The obligation to comply with publication and citation requirements increases the temptation to build scientific output with the help of legally and ethically questionable solutions, among which plagiarism has been making a "career"for many years. However, the list of manifestations of unreliability in research and publications and scientific fraud is getting longer. It is especially influenced by easy access to resources available via electronic open access databases and the growing demand for scientific publications in high-scoring journals.

Teixeira da Silva's article Paper mill-derived cancer research: the improbability of prostate cancer in women, and ovarian and breast cancer in men published in a recent issue of Nowotwory. Journal of Oncology exposes the dark side of the institutionalized mechanism of custom-made fictitious research results (so-called paper-mills) and the imperfection of the system of reviewing medical texts. The author describes a glaring example of a publication from a journal indexed in Web of Science and PubMed (the European Review for Medical and Phar- macological Sciences, IPF 3.024 in 2019), which presented, among other things, high statistics of prostate cancer in women. Moreover, this is not an exception [1]. Da Silva calls this phenomenon as an urgent-to-treat "academic cancer", and this diagnosis - unfortunately - is highly accurate.

In contrast to other forms of abuse committed by researchers (e.g. plagiarism, theft of research results, multiplication of scientific output), the publicized phenomenon has a new dimension. The problem also concerns reviewers and indexed medical journals.

From the legal point of view, it isn't clear how to assess the incompatibility of such an action with the binding regulations. However, one can determine fraud without specialized medical knowledge, which consists of disseminating fictitious results contrary to basic anatomical knowledge. He will also recognize the severe misconduct of reviewers who allowed the publication of compromising texts. However, how to classify and punish this type of pathology is not easy to answer.

The least problematic is to judge the behavior of authors who publish fabricated or falsified research results. According to the current Code of Ethics of Research Workers, such scientific activity is unequivocally a gross violation of the basic principles of doing science [2]. Ordering data, using universal publication templates with data from a specific research area, and lacking published results verification violate the basic ethical principles underlying science's integrity and credibility. Such activity does not meet the requirement of publishing the results of one's research and the researcher's responsibility

\section{How to cite:}

Ożegalska-Trybalska J. Prostate cancer in women - a rare medical event or a new disease of peer-reviewed science publications? NOWOTWORY J Onco/2021; 71:314-315.

This article is available in open access under Creative Common Attribution-Non-Commercial-No Derivatives 4.0 International (CC BY-NC-ND 4.0) license, allowing to download articles and share them with others as long as they credit the authors and the publisher, but without permission to change them in any way or use them commercially. 
for the social consequences of the formulated conclusions. On the other hand, one cannot speak of a violation of copyright or personal rights. The results themselves (especially those generated automatically) are not subject to protection. An infringement can be considered only in attributing someone else's authorship and not in the case of misrepresentation of one's authorship [3]. However, an author aware of personal and social responsibility, who decides to put his name to an unreliable study, should expect public evaluation and scientific ostracism [4]. Activities of the scientific community (e.g., Retraction Watch or PubPeer platforms), which identify and stigmatize scientific dishonesty, can be effective way of combating it.

Unfortunately, it is more difficult to find formal grounds to question the legality of entities that offer custom-made, paid templates with results, figures or images. As long as they do not reproduce protected content from other publications, they do not infringe the law. This is not an optimistic conclusion, especially as tools that use artificial intelligence to help create fictional scientific results are increasingly available.

The publication of texts such as the title 'prostate cancer in women' is also a problem that undermines the credibility of medical journals, which, after all, enjoy particular prestige and trust compared to other scientific journals. This includes both the new online pseudo-scientific journals, which use lowered publication standards and gaps in accepting submitted texts for review and publication. The substantive review of a scientific article should certainly not be bogus, as peer review measures a journal's quality. Publishers should be held accountable for quality, but they cannot always effectively adjudicate scientific ethics and integrity violations. Instead, in case of doubts about the integrity of submitted or published work, they can initiate appropriate procedures, e.g. following the guidelines of the International Committee for Medical Journal Editors (ICMJE). Recommended by guidelines the Committee on Publication Ethics (COPE) [5] provides instructions for dealing with suspected fabricated data contained in an article submitted for publication or reported manipulation of figures and images [6].

To increase the efficiency of verifying submitted papers and detecting fraud, journal editors can use specialized IT tools (e.g., the tested CrossCheck), employ data integrity analysts [7], and emphasize an effective reviewing system. Undoubtedly, so-called blind reviews cannot be truly blind in the sense that an article qualifies as a publication by blindly approval. It is not the task of reviewers to check whether an article contains accurate information and reliable results [8]. However, the positively reviewed content must not raise obvious suspicions regarding basic medical knowledge and scientific principles. In this sense, the allegations of unreliable review (or rather, lack of it) should be signaled in evident cases - such as those exposed by da Silva.

Although the problem of pathology in the scientific community is not new, da Silva's article is a serious signal that the medical publication ecosystem should be sealed, even if fictitious scientific texts represent a negligible percentage of all publications. When growing public health threats and increasing marginalization of science, a loss of trust in published research can have serious scientific and social consequences.

Conflict of interest: none declared

\author{
Justyna Ożegalska-Trybalska \\ Jagiellonian University \\ Intellectual Property Law Chair \\ ul. Józefa 19 \\ 31-056 Kraków, Poland \\ e-mail:j.ozegalska-trybalska@uj.edu.p
}

Received and accepted: 20 Sep 2021

\section{References}

1. Silva JT. Paper mill-derived cancer research: the improbability of prostate cancer in women, and ovarian and breast cancer in men. Nowotwory. Journal of Oncology. 2021;71(4):255-256, doi: 10.5603/njo.a2021.0039.

2. Kodeks Etyki Pracownika Naukowego, Ill wydanie, Załącznik do uchwały Nr 2/2020 Zgromadzenia Ogólnego PAN z dnia 25 czerwca 2020 r., s. 13. https://instytucja.pan.pl/images/2020/kodeks/Kodeks_Etyki_Pracownika_Naukowego_Wydanie_III_na_stron\%C4\%99.pdf(15.09.2021).

3. Ożegalska-Trybalska J. Plagiarism and self-plagiarism - facts and myths. Nowotwory. Journal of Oncology. 2021; 71(1): 71-72, doi: 10.5603/ NJO.2021.0012.

4. Wysocki W, Komorowski A. Jak zweryfikować oryginalność tekstów naukowych? Nowotwory. Journal of Oncology. 2011; 61(1): 85-87.

5. Recommendations for the Conduct, Reporting, Editing, and Publication of Scholarly Work in Medical Journals updated December 2019, p. 8-9. http://www.icmje.org/icmje-recommendations.pdf (15.09.2021).

6. Committee on Publication Ethics, Fabricated data in a submitted manuscript. https://publicationethics.org/files/fabricated-data-submittedmanuscript-cope-flowchart.pdf; Image manipulation in a published article, https://publicationethics.org/files/image-manipulationpublished-article-cope-flowchart.pdf.

7. Triaridis S, Kyrgidis A. Peer review and journal impact factor: the two pillars of contemporary medical publishing. HIPPOKRATIA. 2010; 14(Suppl 1): 5.

8. Byrne JA, Christopher J. Digital magic, or the dark arts of the 21 century-how can journals and peer reviewers detect manuscripts and publications from paper mills? FEBS Lett. 2020; 594(4): 583-589, doi: 10.1002/1873-3468.13747, indexed in Pubmed: 32067229. 